\title{
The Structure and Development of Grinnellia americana, Harv.
}

BY

MELVIN A. BRANNON.

With Plates I-IV.

$7 \mathrm{HE}$ investigations on the reproduction and development 1 of Grinnellia americana were undertaken for the reasons that Grimnellia is distinctively an American species and that little was known of the structure and development of the cystocarp. The work was taken up at the suggestion of Dr. William A. Setchell, Director of the botanical department of the Marine Biological Laboratory at Woods Hole, Mass., and was brought to its present stage in the summer of 1894 . For Dr. Setchell's continuous interest and very valuable assistance in the prosecution of the work I am under deep obligation. Through the kindness of the Trustees and of Dr. William Trelease, Director of the Missouri Botanical Gardens, I occupied the room subscribed for by them during the summers I was engaged in the study of Grimnellia; for this privilege I am also greatly indebted.

Grimnellia americana, as stated above, is distinctively an American Alga, never, so far as learned, having been reported from other waters than those of the west Atlantic coast. It ranges from the mouth of the Weymouth River, Mass., to

[Annals of Botany, Vo1. XI. No. XLI. March, I897.] 
Norfolk, New Jersey, and appears abundantly in Long Island and Vineyard Sounds. The writer has also collected fine specimens at Nantucket. Possessed of brilliant lake-red colour and delicate texture, it constitutes a notable specimen in every representative collection of the New England marine flora.

\section{HISTORY.}

The elder Agardh placed this Alga in the genus Delesseria, which 'then comprehended almost every Alga with a red membranaceous leaf-like frond, and also included within its limits Plocamium and Stenogramme.' It was referred later to Nitophyllum, but was found to differ radically in the form of conceptacle, shape of frond, and position of midrib. For a time it seemed that it was to have fellowship with Hemineura, but the different position of conceptacle, lack of similarity in nervation and ramification, gave sufficient distinction to deny admission to this genus.

After a somewhat careful study of the plant, Dr. Harvey raised it to the rank of an independent genus. He named it Grimnellia, as a memorial to the 'noble conduct of Henry Grinnell of New York, chief promoter of the search after the missing Arctic expedition of Sir John Franklin.'

\section{General, Morphology.}

In his description of Grinnellia, Harvey says that this Alga has a frond which is ' rosy-red, leaf-like, delicately membranaceous, areolated, symmetrical, traversed by a slender percurrent midrib. Conceptacles scattered over the surface of the membrane, bottle-shaped, with a prominent orifice; placenta basal, somewhat prominent, crowned with a pulvinate tuft of subdichotomous spore-threads whose terminal cells are earliest ripened. Spores elliptic oblong or roundish. Tetraspores tripartite, immersed in scattered shapeless cellular warts.'

In addition to these statements regarding the gross anatomy 
of Grinnellia, it should be said that in well-developed plants lateral veins arise from the basal region of the percurrent midrib. In frayed fronds these lateral veins occasionally develop into strong branches, simulating the action sometimes occurring at the tip of the frond after an injury to the apex; viz. bifurcation of the midrib in its subsequent growth. Often these proliferations are the only vestiges of the frayed frond; and thus is demonstrated the fact that clusters of young plants can arise vegetatively by compounding the remnants of the old one. In this respect Grinnellia resembles closely the associated genus Delesseria.

The leaf-like frond is supported by a short somewhat cylindrical stalk which terminates in a dense, disk-shaped holdfast. As Mr: M. C. Potter suggests in his study of the thallus of Delesseria, this differentiation of parts in the frond of Grinnellia gives the single plant a resemblance in structure and functions to a dicotyledonous leaf. The foliar expansion serves as an organ of assimilation; the midrib, veins, and stalk furnish channels for conducting food-material and reservoirs for its storage. This last function is evidenced by the initial growth of numerous proliferations from the midrib and stalk of frayed fronds.

Both asexual and sexual reproduction prevail in Grinnellia americana; and, unlike many of the Florideae, monoecism is never present. The two methods of reproduction and the differentiation of the sexes give certain peculiar characteristics to the vegetative structure of the different fronds.

Male plants are usually much smaller, less abundant, and have more delicate fronds, than either female or asexual individuals. The largest dimensions of those collected at Woods Hole were $7 \mathrm{~cm}$. wide and $15 \mathrm{~cm}$. long. The fronds have a smooth surface, and, if superficially examined, would be considered sterile; but a careful inspection reveals numerous lighter-coloured portions occupying from two to many times the area of the normal cells. Sections through these areas show them to be patches of antheridia producing large numbers of antherozoids. 
The female plants average larger than the tetrasporic. Their cystocarps are arranged promiscuously on either side of the frond, while occasional sections through cystocarps growing base to base were obtained. The cystocarps are cone-shaped, with carpostomes in the crown of each affording a place through which the mature carpospores may escape. Within the fully-developed conceptacle, dichotomous chains of lakered, slightly elliptical carpospores are readily seen by focussing through the pericarp; but the carpospores are so numerous, so densely massed together, and of such deep colour in the mature cystocarps, that one can determine very little of the true structure of this organ by means of optical sections. As in the non-sexual plants, the fruiting-bodies in the male and female frond are less mature near the margin and apex.

On certain cystocarpic plants numerous proliferations are developed on both sides of the frond. These plants are apparently healthy and normal in all other respects. The proliferations may become greatly developed and give the plant an unusual appearance, very similar to that of leaves bearing many small galls. These outgrowths are composed usually of from two to three axial rows of cells corresponding to those of the frond, except that their contents are clear and granular. These cells are surrounded by one or two layers of smaller cells, having the characteristic lake-red colour of the frond (Fig. I4). An unusually fine opportunity for the study of the origin and development of the cystocarp is offered by these proliferations (Figs. 3, 14, I7). They were critically examined in whole and sectioned preparations, in stages from the earliest formation of the procarp to the mature cystocarp. The cystocarps thus developed often appeared pedicellate on account of the length of the proliferation, in the outer end of which they were borne (Fig. 3). No tetrasporic or antheridial plants were found bearing these proliferations.

The asexual plants outnumbered the female even during July and August, the period when the latter reached their maximum number at Woods Hole. In shape, colour, and 
texture of frond the mature tetrasporic plants are very similar to the cystocarpic, but the decided contrast between the rough, shapeless, tetrasporic incrassations and the smooth conical cystocarps, easily enables one to distinguish them unaided by the microscope. Each incrassation contains from four to forty tripartite tetraspores, which closely resemble the carpospores.

\section{HABITAT.}

Grinnellia has been described by Dr. Harvey as an Alga growing ' on stones and shells in four or five fathoms of water.' In the collections of Grinnellia made at Woods Hole and Nantucket it was found growing abundantly on the piles of wharves, at a depth of one to one and a half fathoms below high tide-mark. After severe storms it frequently drifts ashore in company with many other Algae which are torn from the slightly submerged rocks and shells.

Along the Massachusetts coast it thrives best in quiet waters, though fine specimens are seen on rocks and shells submerged one to two fathoms in the 'holes' connecting adjoining bays and indentations, through which the tidal currents run at a speed of eight to ten miles an hour. Mr. Isaac Holden has kindly allowed me to quote from his observations of this Alga made at Bridgeport, Conn., where it attains very considerable dimensions, his largest mounted specimens giving the royal measurements of $25 \mathrm{~cm}$. wide by $65 \mathrm{~cm}$. long. He says he has found it growing in strong tide-currents, but that it acquires its most luxuriant growth in quiet waters, thus corroborating the observations made along the Massachusetts coast. He has collected it from just below low water-mark to the depth of six fathoms, and has secured many fine specimens from the bottom, when wading at low tide, bringing with them the stones or shells, particularly oyster-shells, to which they were attached. Early in August adult plants are very apt to become detached and float in large numbers. From this last observation it appears that the mature plants afford their spores a rapid and wholesale method of distribution. 


\section{General Histology.}

The entire surface of the plant is covered with a thick gelatinous secretion, which causes it to adhere firmly to paper when mounted.

The vegetative cells, forming a single layer in the foliar expansion of the frond, are polygonal in shape, have thick cell-walls, protoplasm peripherally arranged containing granular material, a large nucleus, and a great number of red chromatophores (Fig. I $f$ ). These chromatophores are also found in the superficial cells of the midrib, the stalk and the upper surface of the holdfast. The cells in the apical and marginal (merismatic) portions of the frond are smaller, have more delicate cell-walls, and are far more active than those in the middle and basal regions of the frond.

The midrib is three to five layers of cells in thickness. The central cells are very large, elongated, and angular. The superficial cells are much smaller and more circular than those in the centre. All of them have a thick cell-wall and a thin peripheral layer of protoplasm containing a large amount of granular material (Fig. I $m$ ).

Transverse sections of the dense disk-shaped holdfast show that it is composed of a central region of large oval and oblong ceils surrounded by layers of cells which gradually diminish in size and increase in numbers toward the surface of the organ, where they are quite uniformly roundish and form a strong cortical region (Fig. 2). Surrounding the entire holdfast is a very thick yellowish coat of cellulose, through which project many small rhizoidal filaments. These filaments are composed of one to many rows of thin-walled cells, and serve to absorb food-material as well as to fix the plant more firmly to its substratum. The cells of the holdfasts are completely filled with protoplasm and granular material; have a gelatinous, cellulose cell-wall, and are connected with one another by protoplasmic pits.

Sections through the holdfast, midrib, and frond show protoplasmic pits connecting adjoining joint-cells. It is not 
possible to demonstrate that open communication for interchange of nuclei, chromatophores, and other protoplasmic products between adjacent vegetative cells is established by these pits. In Schmitz's discussion of them he says they are traversed by plasma-cords which serve for conduction of dynamic influences from cell to cell. He thinks that a transfer of dissolved food-material from cell to cell is facilitated because of the pores in the separating membrane of the pit, but that migration of protoplasm by means of these open communications is inadmissible. He further states that open communication between cells of Algae is rare, and that when formed, as in Corallineae, the pores result from the subsequent modification of the common dissepiment of adjacent thalluscells.

His views regarding the pits between thallus-cells of Algae are evidently correct with reference to the organic connexion of the cells of Grinnellia, with one exception-the connexion between the procarpic cells. As will be seen in the discussion of the procarp, the procarpic cells are connected, not by pits, but by open pores, which are established, possibly, in the manner ascribed by him to Corallineae.

\section{PHYSIOLOGY.}

Plants were found growing on the outer surface of the outermost piles of wharves at Nantucket and Woods Hole, having an eastern, southern, and western exposure to sunlight ; while very few plants were found on the exposed surface of the north piles. Whether this was due to lack of light can hardly be stated, as other conditions, decidedly unfavourable to growth, were present. Not a single plant was found on the inside of outer piles nor on the outside of piles in any great degree shaded, while several other Algae belonging to the groups of the Chlorophyceae and Rhodophyceae were discovered growing in these places. This indicates that Grinnellia is far more dependent upon light than many of the Algae associated with it. 


\section{Brannon.-The Structure and Development of}

While direct sunlight appears necessary for the continued growth of the plant, it cannot endure strong light when only slightly submerged. If after collection the plants are placed in water in a shallow vessel, exposed to the direct rays of the sun, their normal colour rapidly changes to a brownish yellow, and they give every evidence of rapid decay, evidently due to the effect of direct sunlight and the accompanying rise of temperature. Direct experiments were not made to determine the sensitiveness of Grinnellia to changes of temperature alone, but incidentally it was observed that a sudden variation of $10^{\circ}$ to $15^{\circ} \mathrm{C}$. from normal (temperature of $15^{\circ} \mathrm{C}$. in the water of Vineyard Sound) for any length of time is destructive to the tissue. Fishermen reported collections of this plant in the winter. Having cut through the ice they could scrape it from the piles, in water of which the temperature was probably not lower than $2^{\circ}$ to $5^{\circ} \mathrm{C}$., while in the summer the temperature of these waters, as previously stated, is $15^{\circ}$ to $17^{\circ} \mathrm{C}$.

The three types of fronds, antheridial, carposporic, and tetrasporic, show a similar degree of sensitiveness to direct light and sudden rise of temperature, but can be preserved in a normal condition for several days in the laboratory if properly shaded, if the normal temperature of the containing water be maintained, and if the sea-water be changed every thirty-six to forty-eight hours.

Nowhere are the effects produced by the change of light and temperature more perfectly shown than in the process of sporing and germination. The spores are liberated in great numbers during the night, particularly the second night after the plants are collected. However, numerous experiments proved that this process occurs in some degree during the day, differing in this respect from the sporing methods observed in some other Florideae, notably Champia parvula.

Immediately after collection, the carposporic and tetrasporic plants were separated in order to study the germination of their respective spores. It was found that the carpospores are usually closely grouped in great numbers immediately 
beneath the cystocarps from which they come, while the tetraspores are promiscuously distributed in much less abundance over the bottom of the dish. A gelatinous secretion begins to form about both carpospores and tetraspores very soon after they pass into the water, which serves to protect, to hold the spores together, and to fix them to the bottom of the dish or other substratum. The fact that they immediately fall to the bottom of the containing vessel shows that they have a greater specific gravity than the frond, which is probably due to the fact that their chromoplasts and other contents are denser than those of the cells of the parent frond.

In a few hours after the liberation of the carpospores they are so thoroughly fixed to the substratum by the gelatinous secretion, that it is necessary to subject them to the full force of a strong stream of water in order to loosen them. So far as could be determined by experiment, they become much more firmly attached than the tetraspores, which, in every case, are found to be easily detached from their position before germination. These phenomena lead to the belief that the special function of the asexual spores of Algae is identical with that of the asexual spores of Fungi; viz. immediate distribution. The carpospores differ so little in colour and shape from the tetraspores, both being lake-red and elliptic-oblong, that they are scarcely distinguishable from one another. They agree closely in size, averaging $30 \mu$ by $50 \mu$, just preceding liberation. Shortly afterward they become more spherical and enlarge to $3^{6} \mu$ by $4^{8} \mu$. On account of the densely aggregated chromoplasts in the newlydeposited spores, it is extremely difficult to distinguish the nucleus. However, when treated with five per cent. acetic, or one per cent. picric acid for ten minutes, washed thoroughly in distilled water, and then stained with Delafield's haematoxylin, the nucleus of each spore is readily recognized. 


\section{Germination of SpOREs.}

The carpospores and tetraspores having been separated in the manner above mentioned, experiments in germination were undertaken without possibility of confusing the respective action.

Because of Protozoa and minute Crustaceans, which greedily devoured the growing spores, great difficulty was experienced in the observation of their development. Immunity from these creatures was obtained by using water which had been kept for an hour at a temperature of $95^{\circ} \mathrm{C}$., so as to secure a high temperature with but little evaporation, and thus to prevent a larger percentage of salt than is present in normal sea-water. Had water containing an excess of salt been used, it would have proved, according to Oltmann's experiments, destructive to germination.

After the water had cooled sufficiently, it was slowly filtered through a sand and cotton filter, an operation which secured a twofold object-removal of foreign bodies, and thorough aeration. Following these methods, the germination of carpospores and tetraspores gave very satisfactory results.

In the beginning of the process of germination, the gelatinous envelope, which upon application of chlor-iodide of zinc gives a cellulose-reaction, is secreted, and is arranged in two to three concentric layers about the carpospores (Fig. $5 b, c, d$ ); while the single layer which surrounds the tetraspores is comparatively thin and homogeneous. With subsequent imbition of water the spores swell and become lightercoloured, the form also changing from elliptical to egg- or oval-shape (Figs. $4 a, b ; 5 b, c, d$ ). Cell-division first makes itself manifest by transverse fission at the apical end, from twenty-four to thirty-six hours after the spores are deposited, a process which is usually repeated at corresponding intervals, giving rise to a filament of from three to five cells. While this filamentous growth is taking place at the apical end, simultaneous or closely succeeding development begins at the basal portion of the spore (Fig. $\left.6 b, b^{\prime}\right)$; and after the 
formation of three to six transverse walls, lateral branches develop, forming the holdfasts of the young plant (Fig. $7 \mathrm{~h}$ ). These are usually only a few cells in length, irregular in outline and incurved at the tip, enabling them to fix the young plant firmly to its substratum. Because of the nature of its holdfasts, the young fronds are often found growing in epiphytic fashion on older Grimnellia-plants and other Algae.

At this period, the rapid growth in the middle of the filament is characterized by the appearance of vacuoles and the rearrangement of chromatophores in such definitely transverse and radiating lines that the appearance of celldivision is produced. As the spore continues developing, these lines of chromatophores are arranged lengthwise of the cells (Fig. $7 c$ ), vacuoles appear and the colour of the contents becomes much lighter and almost disappears in the outer terminal cells of the filament (Fig. $7 v$ ).

Cell-division in the germinating spore is limited to one plane until the formation of a frond proper begins, when fission takes place in two planes along the lines of the collected chromatophores; and subsequently, with the development of the midrib, occurs in three planes in the median region of the frond.

For frequent observation of the progress of germination, pieces of mica were placed beneath the fronds until sufficiently covered with spores. The mica was then transferred to shallow dishes of water, and was examined often during the early stages of spore development. This recurring disturbance proved injurious to the spores, and they seldom survived the treatment longer than a week. When unmolested and supplied with fresh water daily, they continued to grow for a period of two to three weeks.

To determine the varying effect of different rays of light upon their development, dishes containing spores were covered with colourless, red and blue glass respectively. These receptacles were then protected from direct sunlight, and supplied with the boiled sea-water which was changed every thirty-six to forty-eight hours. The spores under the colour- 
less glass gave much better results than those in open dishes, living from ten to thirteen days, which was due, perhaps, to the exclusion of dust and the maintenance of a lower temperature. The average of results of experiments with carpospores and tetraspores shows that they live for a longer time, attain greater size, and possess a more vivid colour when kept under blue glass than when covered with red, and in both instances give more satisfactory results than those germinating under the colourless glass. These conclusions, while not final, give additional weight to the belief that this plant is particularly sensitive to light.

Under the most favourable conditions (beneath blue glass), the spores developed into young fronds of twenty-four cells; and on adult fronds collected, young plants of exactly comparable development were found growing in epiphytic fashion.

With the addition of these and more advanced forms, it was possible to pass in review the successive phases from the unicellular spores to the fully-developed membranaceous fronds.

Not only does Grimnellia reproduce itself by means of spores, but also vegetatively, in two ways. First, by the method referred to above where proliferations arise from the remnants of frayed fronds. Very many of these specimens were collected in the latter part of the season from piles which had been scraped earlier in the summer, at which time only fragmentary fronds of Grinnellia had been left attached. The second method of vegetative reproduction was observed in small portions of the frond which had been severed accidentally from the parent plant. These fragments, containing a short portion of the midrib, attached themselves by their cut ends to the bottom of the porcelain dishes, and grew vigorously as long as they were supplied with the usual favourable conditions.

\section{Development of Antheridia.}

In his work on the fructification of the Florideae, Dr. Schmitz states that, in all cases examined, the reproductive organs 
originate and develop by apical growth: 'An diesem Thallus entstehen die Sexualzellen durch Differenzirung einzelner Endzellen des ganzen Systems verzweigter Zellfäden.'

Grinnellia americana seemed an exception to Schmitz's law of development, because of the patches of antheridia and the cone-shaped conceptacles which originate from the membranaceous male and female fronds. Dr. Schmitz does not mention this peculiar Alga, which was probably inaccessible to him. To prove, therefore, whether this genus is an apparent or a real exception to his law, made the study of its development exceedingly interesting.

In the development of the antheridia, individual vegetative cells in different parts of the frond are observed to change from a pronounced red to a lighter colour, possibly due to an accompanying development of a large amount of granular matter of a highly refractive character. Similar changes are observed to follow immediately in many of the cells adjoining these centres, causing the male fronds to be patched promiscuously on both sides with numerous collections of these lighter-coloured granular cells. These individual groups occupy irregular areas varying from two to twenty times the surface of the average vegetative cell, and are covered with a thicker gelatinous layer than the vegetative portion of the frond (Fig. 9). Cross-sections of these regions show that the significance of the excessive granular substance in this instance is the modification of vegetative tissue in preparation for the formation of reproductive elements. The sections were prepared from antheridial fronds which had been stained two hours in Delafield's haematoxylin. They show that the modified vegetative cells divide transversely, and that each of the daughter-cells repeats the process at both ends, in a plane at right angles to the first plane of division, thus giving rise to three layers of cells instead of one (Fig. 8).

The protoplasm of the cells last formed collects into a dense mass at the distal end and forms a spherical body, which separates by a constriction of the cell-wall below it. (Fig. $8 d, d^{\prime} c, c^{\prime}$.) The spherical cell thus formed is an antherozoid. 


\section{I4 Brannon.-The Structure and Development of}

Presently these small spherical bodies separate from their mother-cells and pass into the gelatinous layer which covers the patches of antheridia.

These antherozoids are non-motile, consequently depending upon water-currents for distribution so as to come into contact with trichogynes. Repeated tests for their nuclei gave negative results, though the granular contents show deeplystained fragmentary particles.

Because the male plants are smaller and apparently much more rare than the female, and produce non-ciliated antherozoids, it is obvious that the male plants must generate an extraordinarily large number of them. This demand is abundantly supplied by the myriads of antherozoids developed in the apical manner described above.

\section{Development of THE Cystocarp.}

The method of the development of the cystocarps, which are promiscuously distributed on either side of the female frond of Grimnellia, appears more difficult to harmonize with the theory of Schmitz than does the manner of formation of the frond and the antheridia. The study of the initial development of the cystocarp, however, not only shows that it conforms to his theory of the development of most of the Florideae, but further testifies that the whole tissue of this leaf-like Alga is developed by apical growth of ramifying threads. In the apical and marginal regions of partially mature female plants, and distributed promiscuously over the entire surface of young female fronds, are isolated individual cells assuming a triangular shape (Fig. IO). They are directed apically outward and upward in such a manner that if a line were drawn through the long axis of any one of them to the median plane of the frond, an angle of $50^{\circ}$ to $75^{\circ}$ with the midrib would be formed. These are centres of active growth, and develop groups of cells (Fig. I I and Fig. I 2) similar in appearance and outline to those at the apices of the growing plants. After twenty to thirty cells have been 
formed in the plane of the frond, growth begins in the third plane, producing a papilla-like thickening in these portions (Fig. I3).

The procarp consists of three cells and arises as a lateral branch from one of the large joint-cells in the plane of the frond (Fig. I4). In the haematoxylin preparations of mature procarpic cells it is found that each contains a well-defined nucleus within the densely granular, protoplasmic contents, and that these cells are connected by open pores which perforate their delicate cell-walls. The granular material passing through these pores gives a beaded, strand-like appearance to the protoplasmic connexion between adjacent procarpic cells. The basal procarpic cell is frequently the smallest in the branch and is connected with the supporting cell by a pore, and not by a pit as are the four contiguous thallus-cells which, with the supporting cell, form a characteristic group in the floor of the young cystocarp.

It is possible that the early connexions between the cells of the procarpic branch were pits which became open pores by the absorption of the delicate cell-wall at the points of communication.

The uppermost cell of the procarpic chain becomes the carpogonium from which the trichogyne develops (Fig. I4 tr). The trichogyne is subject to considerable variation. In some instances it is branched and much elongated (Fig. I $7 b$ ); in others it is simple, twisted, and of moderate length (Fig. 15). The granular protoplasmic contents of the trichogyne are in marked contrast to the clear gelatinous sheath enveloping it. Just above the carpogonium, a knee-shaped enlargement frequently occurs (Figs. 14 and $17 k$ ). At this point the longitudinal axis of the trichogyne changes its direction and makes an angle of $30^{\circ}$ to $40^{\circ}$ with its former axis. This enlargement on one side of the basal region may be the cause of the changed direction of growth in the trichogyne, or may be an accompanying phenomenon due to the resistance which the young trichogyne must overcome when pressing between the cells of the rapidly-forming pericarp. 


\section{i6 Brannon.-The Structure and Development of}

In Schmitz's discussion of the origin of the female sexual cells of the Florideae, he states that without exception they develop from the end-cells of shorter or longer side-branches of the whole system of ramification of thallus-filaments; that these branches are formed sometimes as secondary sidebranches subsequently to the formation of other ramifications; and that, in all cases, the female sexual cell, the carpogonium, is formed from the end-cell of the side-branch by permitting a process to project from its apex which develops into a more or less long hair-like trichogyne.

As has been shown in the foregoing description of the origin of the procarpium and carpogonium, Grinnellia agrees with many of the Florideae in the development of these organs.

It was impossible to discover antherozoids fusing with the trichogynes of freshly collected material, therefore several young female fronds were placed in a dish of water and covered with antheridial plants. The same degree of care was observed with respect to the change of filtered sea-water at stated periods and the excess of light and heat as had been found necessary in the successful germination of spores and the preservation of living Grimnellia plants. Very satisfactory results followed, and several cases of fusion and partial fusion were found in sections of specimens artificially brought together.

The carpogonium is fertilized by the fusion of one or more antherozoids with the trichogyne (Fig. I9 $a$ ). It was impossible to identify the nucleus in the antherozoids, and equally difficult to determine whether the trichogyne possessed a nucleus. Hence no union of nuclei was observed when the cell-contents of the antherozoid were intimately associated with those of the trichogyne. In the latter there were individual and grouped particles, which took a deeper stain when treated with Delafield's haematoxylin than the surrounding non-granular substance.

In somewhat older specimens the trichogyne is separated from the fertilized carpogonium by a cellulose plug which is 
formed in the neck of the trichogyne. Shortly after this, zoogloea-bacteria collect about the distal end of the trichogyne and cause its rapid disintegration (Fig. $\mathrm{I}_{4} b$ ). This shows the evanescent character of the organ, which decomposes and falls away in a short time after receiving the contents of the fusing antherozoid.

As there is no indication of a conjugating tube connecting the carpogonium to the large auxiliary cell which supports the procarpic branch, and as there are open pores connecting the cells of the procarpium, it seems evident that, with the substitution of pores for pits, Bornet's explanation of the method of propagating the fertilizing influence from the carpogonium to the cell which develops the sporiferous tissue must be accepted in this Alga.

Very soon after the fertilizing contents of the carpogonium have been transmitted to the auxiliary cell (the large thalluscell which supports the procarpic branch), it begins an active growth. It increases in size, develops a very thick cellulose cell-wall, and becomes gorged with dense, yellowish, protoplasmic contents. A similar and accompanying phenomenon is observed to occur in the four large auxiliary cells which immediately surround this supporting cell of the procarp and are found in the plane of the frond (Fig. 16).

These cells are nucleated, have the same general position with reference to one another (Fig. 25), and form a distinctive group in all young cystocarps.

In their study of Gracilaria, Bornet and Thuret refer to a group of cells in the basal region of the fruiting body which resemble this group in Grinnellia. In a subsequent investigation of the procarpium and fruit of Gracilaria, Mr. Johnson mentions the same cells and considers them a part of the procarp. In Grinnellia they are auxiliary cells of which the central one develops the sporiferous tissue subsequently to receiving the fertilizing influence of the carpogonium.

The developmental changes in the young cystocarp are very rapid from this period. The central cell of this group, 


\section{I8 Brannon.-The Structure and Development of}

as noted, is the centre of growth of the sporiferous filaments, and the four adjacent cells receive and supply food-material for the development of the sporiferous tissue. In all preparations of a certain stage it was observed that the central cell gave rise to an upper and a lower daughter-cell (Fig. 20 b,c). These cells contained the same dense, yellowish, protoplasmic contents which characterized the cell from which they came. The daughter-cells, resulting from the division of the upper cell (Fig. $26 d$ ) multiply rapidly and soon form a papilla $(p a)$ of four to six cells extending from the floor obliquely into the cavity of the cystocarp. The plane of cleavage in the cells of the papilla is not regular but angular and concave on the upper surface of older, and convex on the lower surface of younger cells (Fig. 18). Marginal cells are cut off from the surface of these and give rise to most of the sporiferous filaments (Fig. 23). All of these cells are connected by pits and contain the same dense, yellowish, protoplasmic contents which characterized the auxiliary cells.

Sporiferous filaments continue to originate at different times, so that in a median longitudinal section of a partially mature cystocarp fully developed spores may be found on one side, and half mature to very young ones on the other (Fig. 22).

The sporiferous filaments have a somewhat unique, though uniform, method of development. They usually grow in the form of a central chain of cells, from each unit of which a whorl of branches is developed consisting of two to three cells (Fig. 24). Primarily, the cells of each branch are connected by long protoplasmic filaments (Fig. I 8 pi), but the cells gradually enlarge until this neck-like connexion is so abbreviated that they are almost in contact, showing merely a simple protoplasmic pit in the very short connexion between their walls (Fig. $23 p$ ). These enlarged cells become densely filled with protoplasm and give rise to the dichotomously branching chains of carpospores. Usually three to five carpospores originate from each sporiferous branch by repeated abstriction of its terminal portion (Fig. $23 \mathrm{c}$ ). At first the carpospores are small, irregular in form (Fig. $26 \mathrm{c}$ ), 
and possess a clear granular appearance. Presently they enlarge (Fig. $26 c p$ ), passing through an elongated oblongelliptical form (Fig. $26 c^{\prime}$ ) to a true oval or spherical shape (Fig. $26 \mathrm{~m}$ ). As the spores gradually increase in size, they acquire a reddish colour which finally becomes a lake-red, the characteristic colour of all mature spores of Grinnellia. This process is repeated by every one of the sporiferous filaments developing from the large central basal cell, in this way giving rise to a very large number of carpospores, averaging from 300 to 400 , in every mature cystocarp. The stimulation resulting from fertilization of the young cystocarp is manifest not only in the origin and active growth of the sporiferous filaments, but also in the rapid development of other portions, such as the pericarp, basal cortical tissue and sterile filaments (Fig. 21).

From the moment the joint-cell at the base of the procarpic branch begins to enlarge and acquire dense protoplasmic contents, the growth of the pericarp is accelerated. The cells on the upper surface of the cystocarp multiply rapidly and become elevated by the growth of tissue in the fruiting portion of the young cystocarp. As this surface-tissue, which is to form the pericarp, further develops, it is apparent that its irregular arrangement of cells is becoming regular, and that a number of filaments, growing apically, are united with each other by lateral branches. These pericarpic filaments not only branch in the surface-plane of the pericarp, but also at right angles to that plane, forming two- to three-celled branches which are connected with the terminal cells of the sterile filaments within the cystocarpic cavity (Fig. I $8 s p$ ). The branches from the pericarpic filaments decrease as the filaments grow outward and upward until their apices are in contact and form a circle about an open portion over the central region of the cystocarpic cavity. These filaments now change the direction of growth, which had previously formed an angle of $60^{\circ}$ to $75^{\circ}$ with the surface-plane of the frond, so that they grow almost at right angles with that surface (Fig. $22 \mathrm{cr}$ ). The apical cells divide four to six times and growth dis- 


\section{Brannon.-The Structure and Development of}

continues. Thus a cone-shaped wall is developed about the cystocarp, and a carpostome, very rarely two, is formed in the apex of the cystocarp by the circularly-arranged terminal cells of the pericarpic filaments.

The lower cortical tissue, composed of a few cells at the time of the fertilization of the procarp, begins to increase immediately after fertilization and forms a supporting tissue of four to six layers of cells between the floor or basal cystocarpic cells (consisting of the five auxiliary and the surrounding cells lying in the horizontal plane of the frond) and the pericarp, enclosing the lower portion of the cystocarp (Fig. 22 c). These cortical cells have thin walls and clear granular contents, indicating that their function is, at least partially, transmission of food to the mother-cells of the sporiferous filaments.

The body-cavity enlarges, pari passu, with the development of numerous sporiferous and sterile filaments, the latter connecting the cortical tissue at the base of the cystocarp with various portions of the rapidly developing pericarp.

These sterile filaments consist of a few, long, narrow cells having an appearance similar to that of the cortical cells (Figs. $18,26 s f$ ). The function of these filaments is somewhat problematical. The fact that they originate from the basal cortical region of the cystocarp, which is in immediate contact with the group of dense, protoplasmic, auxiliary cells, from one of whose daughter-cells the sporiferous tissue develops, and that they are joined to the pericarpial wall, strongly suggests that their function is to conduct nutritive material from the pericarp through the cortical tissue to the mother-cells of the sporiferous filaments. It seems hardly probable that they afford a support to the pericarp, as it is composed of two to three layers of cells arranged in the manner of an arch about the body-cavity of the cystocarp (Fig. 2I pr).

The fact that the cells given off in whorls from the central cells of the sporiferous filaments are small with clear sparsely granular contents at first, in subsequent development becoming greatly enlarged and crowded with dense granular substance, 
gives additional testimony to the belief that the sterile filaments connecting pericarp and cortical cells in the base of the cystocarp (Fig. 2I) are agents for conducting food-material from the pericarp to the egg-cells of the cystocarp.

In Mr. T. Johnson's work on Sphaerococcus and Gracilaria, he figures and describes a complicated fusion of the procarpic cells shortly after fertilization of the trichogyne. A very large cell is the result of this fusion of several cells and from this the ooblastema-filaments develop. Nothing of this nature is discovered in the growth of the cystocarp of Grinnellia. It seems, on the contrary, that the large protoplasmic companion-cells simply contribute nourishment to the large central cell through the pits in the walls of their connecting processes (Fig. 26 ) , and that this large cell gives rise to a few ooblastema-filaments and to a papilla-like growth of cells containing dense protoplasmic contents from which nearly all the ooblastema-filaments develop (Figs. 24, 25). In this way the production of these filaments is continued at different intervals and gives rise to chains of carpospores of various ages, ranging from mature to very young forms (Figs. 22, 26).

The lack of fusion in the auxiliary cells of Grinnellia is one of the most notable points observed in the study of its development. It is especially peculiar, as fusion of basal, procarpic cells has been reported in the related genus Gracilaria. A careful examination of a very large number of stained and unstained preparations of median longitudinal and transverse sections of young and old cystocarps failed to reveal a single case of cell-fusion. The cell-walls of the old, empty, auxiliary cells in the base of the mature cystocarps were unabsorbed, though often irregular and distorted, because the cell-contents had been used in supplying food-material to the ooblastema-filaments and carpospores. As only a thin membrane is left to mark the cell-walls of the empty auxiliary cells, the freezing method was especially valuable in exactly determining whether there had been any true fusion of adjacent cells. Any process employed in preparation for sectioning, which would have produced even a slight rupture 
in the frail walls of these old exhausted cells, would almost certainly have given preparations showing the empty cells connected by wide openings, thus leading to the conclusion that cell-fusion between these auxiliary cells had taken place.

During much of the time devoted to the initial study of Grinnellia, many attempts were made to carry it through paraffine for the purpose of sectioning, but none were successful. It was found on examination from time to time, as the plants were being prepared for imbedding, that they endured the action of absolute alcohol and the oils very well; but in every case the tissue was found to be too delicate to endure the temperature necessary in the final process of imbedding, even when the softest paraffine, melting at the low temperature of $45^{\circ}$ C., was employed.

After repeated failures with paraffine the celloidin method was tried. This proved somewhat more satisfactory, though the prolonged treatment of sections with the oils used in dissolving celloidin shrivelled and distorted them to such an extent as to render observations partial and uncertain in their results. Finally, having secured an abundance of favourable material, and adopting the freezing methods and apparatus perfected by Mr. W. J. V. Osterhout of Brown University, the successful study of the cystocarpic development of Grinnellia was undertaken, and very gratifying results obtained.

The great advantages of the freezing method in work on Grinnellia are appreciated in the ability to make rapid preparation of fresh tissue and to secure a great number of sections with comparatively little labour. This latter advantage makes the process especially valuable in showing the relation of the evanescent trichogyne to the procarp. It is difficult to observe this relationship by other methods, since many of the cystocarps may be too young or too old by a few days to show clearly the early stages of procarpic development.

A brief summary of this method may be given as follows:A portion of the fresh frond is arranged in several layers, 
held firmly together and placed in dilute gum-arabic on the freezing chamber. In a few minutes it is frozen sufficiently for sectioning.

The sections in this work were cut .03 $\mathrm{mm}$. in thickness, and, mounted in dilute glycerine, were ready for examination.

In some cases sections were stained with Delafield's haematoxylin in order to bring out distinctly the thin gelatinous coat which surrounds the procarpic cells and, in more advanced stages of the cystocarp, the thick cell-walls of the auxiliary cells and ooblastema-filaments.

To summarize the chief points developed in the study of Grinnellia americana:-

I. Grinnellia americana is distinctively an American marine Alga. It was erected into an independent genus by Dr. Harvey.

2. There are no distinctive differences in the vegetative structure of the male, female, and tetrasporic fronds.

3. This Alga flourishes most luxuriantly in quiet waters. In such conditions the fronds separate from their holdfasts late in the summer; and, rising to the surface, are carried away by the shore-currents, thus effecting a wide and wholesale distribution of the fruiting bodies.

4. The cells, vegetative and reproductive, are nucleated, surrounded by thick cell-walls and, with one exception, connected with one another by protoplasmic pits. In the case of the exception, the cells of the procarp, they are connected by open pores.

5. Adult plants are very sensitive to intense light and increasing temperature; but, on the other hand, will not grow in shady places.

6. Mutilated plants proliferate readily, and thus a single frayed frond may give rise to a large number of vegetativelyproduced plants. Not only do these proliferations develop when injured, but the female plants frequently bear proliferations, in the terminal end of which may be found a cystocarp, which appears pedicellate.

Plants may originate vegetatively by regeneration of the 


\section{Brannon.-The Structure and Development of}

frond from small portions which have been cut from the parent plant.

7. It is found by experiment that the carpospores and tetraspores are excellently adapted to the study of the various phenomena attending germination, for while they respond readily to change of intensity of light, temperature, and salinity of the surrounding water, yet they are sufficiently hardy to develop into young plants when artificially supplied with favourable conditions.

8. The non-motile antherozoids are developed in enormous numbers by the abstriction of the terminal portion of the apical cells of the antheridia.

9. The cystocarp begins to develop by the modification and apical growth of a joint-thallus-cell.

Io. The procarp, consisting of three cells, is developed from the supporting thallus-cell in the base of the young cystocarp. Its apical cell becomes the carpogonium. Subsequently, the fertilized contents of the carpogonium are transferred through the open pores connecting the procarpic cells to the supporting thallus-cell which becomes the central one of the five auxiliary cells.

II. The trichogynes are often branched, and as many as five simple ones may grow from a cystocarp borne on a proliferation.

12. Fusion of the antherozoid with the trichogyne results in great stimulation to the thallus-cell at the base of the procarp, and rapid disintegration of the trichogyne, which is a very evanescent organ.

I3. The sporiferous filaments are developed as chains of central cells, from each of which a whorl of spore-producing threads may originate.

I4. The carpospores arise acropetally from the branches of the sporiferous filaments, and not interstitially.

I5. The development of the cystocarps of Grinnellia agrees with that reported for Gracilaria in that the body-cavity develops schizogenetically, and that the sterile filaments connect the pericarp with the cortical tissue below the group 
of highly refractive, yellow cells at the base of the procarpium. It differs in that the pericarp is only two to three layers of cells in thickness, and that no fusion of cells is observed in the basal cystocarpic region of Grinnellia. As previously stated, this is one of the most salient points developed in the study of Grinnellia. This subject was more interesting, and received more special attention, because fusion of cells in the basal cystocarpic region had been reported for other Florideae, notably the closely related genus Gracilaria.

16. It is perfectly evident that fusion of cells in the basal region of the developing cystocarp does not occur; but that the large amount of nourishment supplied to the ooblastemafilaments by the cells growing directly from the joint-cell at the base of the cystocarp, is received directly through the pits from the group of densely protoplasmic auxiliary cells in the floor of the fruiting body, and indirectly, by transmission from the pericarp through the sterile filaments.

I7. Grinnellia americana conforms in every phase of development to Schmitz's law of apical growth. This law is exemplified in the germination of the spores, the growth of the fronds, the origin and development of antheridia and cystocarps, and the final separation of antherozoids and carpospores.

State University of North Dakota,

GRAND Forks, NORTh Dakota.

\section{REFERENCES TO LITERATURE.}

Collins, F. S. In Notes on New England Algae, III, Bull. Torr. Bot. Club II : 29, 30, Mr. I884. Records a striking exception to the rule, the presence of characteristic south shore New England Algae north of Cape Cod in Weymouth River and an adjoining cove.

FARLow, W. G. The Marine Algae of New England. U. S. Fish Com. Report, I879, pp. 161, I62.

Harvey, W. H. Ner. Am. Bor., Part II.

Potter, M. C. Jour. Marine Biolog. Ass., pp. i 7 I, I72. 1889. 


\section{Brannon.-The Structure and Development of}

Schmitz, Fr. Untersuchungen über die Befruchtung der Florideen. Sitzungsberichte der kön. Akademie der Wissenschaften zu Berlin, p. $220 . \quad 1883$.

Davis, B. M. Development of the Frond of Champia parvula, Harv. from the Carpospore. Ann. of Bot., Vol. vi, 24. Dec. '92.

Kuckuck, Paul. Review of Oltmann's Ueber die Kultur- und Lebensbedingungen der Meeresalgen, Bot. Centralblatt, 5I, 204-207. I892.

Johnson, T. The Procarpium and Fruit in Gracilaria confervoides, Grev. Ann. Bot., Vol. i, Nos. III and IV.

On Sphaerococcus coronopifolius, Stackh. Ann. Bot., Vol. ii.

Osterhout, W. J. V. A simple freezing Device. Bot. Gazette, XXI, I95-20I. Apr., I896.

\section{EXPLANATION OF FIGURES IN PLATES I-IV.}

\section{Illustrating Mr. Brannon's paper on Grinnellia americana, Harv.}

Fig. I. Transverse section of a frond. $m$, showing the region of the midrib. $f$, the region of the frond which is only one layer of cells in thickness. $\times 125$.

Fig. 2. Transverse section of the holdfast. $c$, thick, yellowish cuticle. co, the cortical portion of the holdfast. $r$, one of the rhizoidal filaments. $\times 7^{2} 5$.

Fig. 3. c, cystocarps borne on the distal end of the proliferations. $\times 30$.

Fig. 4. Two carpospores two days old showing a thick, cellulose cell-wall. $a$, spherical spore before germination, and $b$, the spore having become elliptical in outline shortly after the formation of an apical cell. $\times 500$.

Fig. 5. Three germinating carpospores showing gelatinous coats of cellulose arranged concentrically. $b$, two-celled stage of germination. $c$ and $d$, more advanced and showing apical growth. $\times 500$.

Fig. 6. Carpospore four days old. $b, a, a^{1}$ are the cells which are to produce the foliar portion, and $b^{1}$ the cell which is to develop the holdfast portion of the plant. $\times 500$.

Fig. 7. A tetraspore eight days after beginning to germinate. $h$, a filamentous holdfast. $c$, the longitudinally arranged chromatophores, and $v$, the vacuoles. $\times 500$.

Fig. 8. Transverse section of a cluster of antheridia. $d$, a mother-spermatiumcell with the protoplasm collected in its distal end. $d^{1}$, showing the separation of the young antherozoid. $c$, more advanced, and $c^{1}$ a young antherozoid with shining granular contents completely separated from mother-cell. (Haematoxylin preparation.) $\times \mathrm{I} 200$.

Fig. 9. Surface-view of a patch of young antheridia (an). $\times 3^{2} 5$.

Fig. 10. Portion of the marginal region of a young female frond showing a three-celled cystocarp which is developing apically from a modified vegetative cell. $\times 220$.

Figs. II and I 2 show more advanced stages of Fig. IO. $\times 220$. 
Fig. I3. A surface-view of a young cystocarp showing the trichogyne $(t)$ and the apical cell $(a)$ corresponding to $a$ of Figs. II and I $2 . \quad \times 22$.

Fig. I4. Transverse section of a young cystocarp borne on a proliferation. $t r$, trichogyne. $k$, the knee-like projection at the base of the trichogyne. $b$, collection of Bacteria about the disintegrating apex of the trichogyne. $a$, the carpogonium. po, the open pore connecting the fertilized carpogonium with its hypogynal cell. $d$, the joint-thallus-cell which gives rise to the procarpium. $c$, cortical tissue in the pericarpic region of the young cystocarp. $\times 440$.

Fig. I5. Transverse section of a young cystocarp showing the joint-thallus-cell (b) which gives rise to the procarpic branch. $t r$, twisted trichogyne. a, carpogonium. $a u$ and $a u^{1}$, two auxiliary cells. $\times 440$.

Fig. 16. Tine group of five auxiliary cells which characterizes every young cystocarp. $p$, pit-like connexions. $a$, the thallus-cell which gives rise to the procarpic branch and, subsequently to fertilization of the carpogonium, receives its fertilized contents. $n u$, nucleus which appears distinctly in these cells. $d$, daughter-cell from the central auxiliary cell $(a) . \quad \times 725$.

Fig. I7. Transverse section of a proliferation which bears a young cystocarp having two trichogynes. $b$, a branched trichogyne. $a$, carpogonium. $k$, the knee-like growth on the trichogyne $t r . \quad \times 800$.

Fig. 18. Portion of a transverse section of a young cystocarp. $a$, central auxiliary cell. I, 2 , and 3 , companion-auxiliary cells. $d$, daughter-cell producing an ooblastema-filament and a papilla of densely protoplasmic cells from which most of the ooblastema-filaments develop. The cleavage plane in these cells of the papilla is very irregular. $p i$, protoplasmic pits connecting adjacent sporiferous cells. $s f$, sterile filaments connecting the basal cortical portion of the cystocarp to the inner branch-cells $(s p)$ of the pericarp $(p r) . \quad \times 725$.

Fig. 19. An optical section of a proliferation which has a young cystocarp with two trichogynes (Haematoxylin preparation). $a$ and $a^{1}$, two antherozoids in contact with the trichogyne. $b$, a strongly stained body in the protoplasmic contents of the trichogyne. $\times 440$.

Fig. 20. Transverse section of a young cystocarp in the plane $m n$ of Fig. I6. $a$, the joint-thallus-cell which bears the procarpium and receives the fertilized contents of its carpogonium. $c$, an upper, and $b$, a lower daughter-cell of the mother-cell $(a) . c$ has developed ooblastema-filaments $s p . \quad$ I and 2 are companion auxiliary cells. $\times 575$.

Fig. 21. Obliquely transverse section of a young cystocarp. $a$, central auxiliary cell. $d$, the upper daughter-cell from the mother-cell $(a)$. $p a$, the obliquely developed papilla of cells from which the ooblastema-filaments develop. pi, protoplasmic pit. $s f$, sterile filaments connecting the basal cortical region $(c)$ of the cystocarp with its pericarp ( $p r) . \quad \times 800$.

Fig. 22. Transverse section of a partially mature cystocarp showing chains of mature carpospores $(c y)$ on one side and half mature $\left(c y^{1}\right)$ on the other side. $s f$, sterile filaments connecting the basal cortical tissue to the double-walled pericarp. $c r$, carpostome formed by the surrounding terminal cells of the pericarpial filaments. $\times \mathbf{I} 25$.

Fig. 23. Portion of the transverse section of the papillary cells with marginal cells $(m)$ from which sporiferous filaments develop. $c$, young carpospore abstricting acropetally. $p$, protoplasmic pit. $\times 440$.

Fig. 24. Oblique section through the basal region of the cystocarp. $a$, central 


\section{Brannon.-Grinnellia americana, Harv.}

auxiliary cell with companion-auxiliary cells $(1,3$, and 2$) . d$, upper daughtercell bearing the ooblastema-filaments $(s p)$ which develop whorls of sporiferous filaments from central cells in the chain. pi, protoplasmic pits. $s f$, sterile filament which develops from one of the auxiliary cells surrounding the central one of the auxiliary group. $\times 725$.

Fig. 25. A somewhat later stage of the auxiliary cells than that shown in Fig. 16. of, ooblastema-filament. $p a$, papilla from which other ooblastemafilaments are to develop. $\times 725$.

Fig. 26. Transverse section of a semi-mature cystocarp. $s p$, dichotomous sporiferous filaments which are abstricting young carpospores $(c)$ from their outer ends. $c p$, elliptical half mature carpospores. $m$, mature carpospores which were separated from their parent sporiferous filaments and remained in the cystocarpic cavity of the sectioned body. $d$, portion of the upper daughter-cell from the central auxiliary cell $(a)$. $p a$, papilla of cells which developed from the daughtercell $(d)$. $s f$, sterile filaments, and $p$, protoplasmic pits. $\times 725$.

All figures were drawn by the author. The third figure was drawn from an herbarium specimen. All the others were drawn with the aid of the camera lucida from preparations of fresh material. 


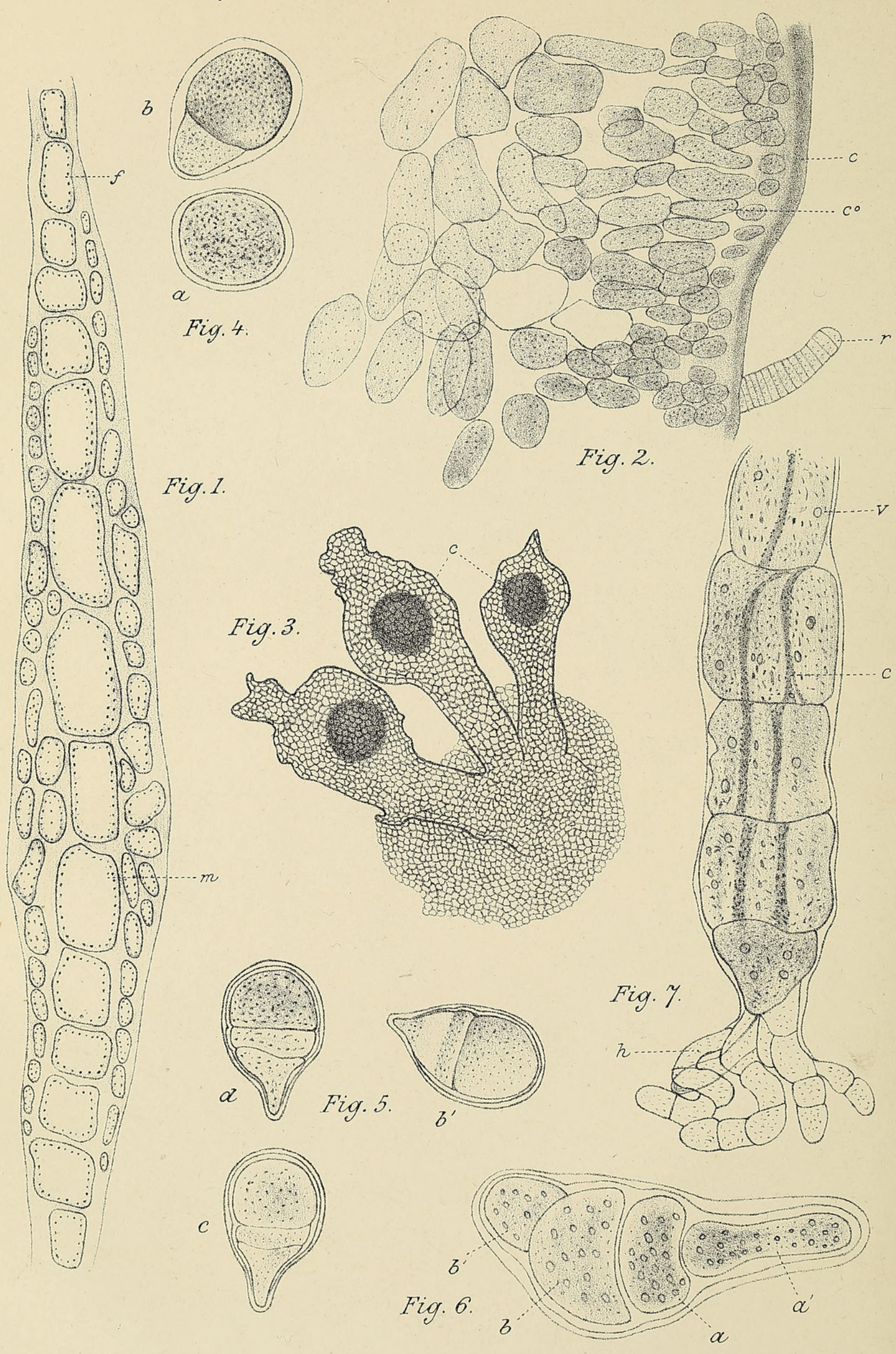


Annats of Botany

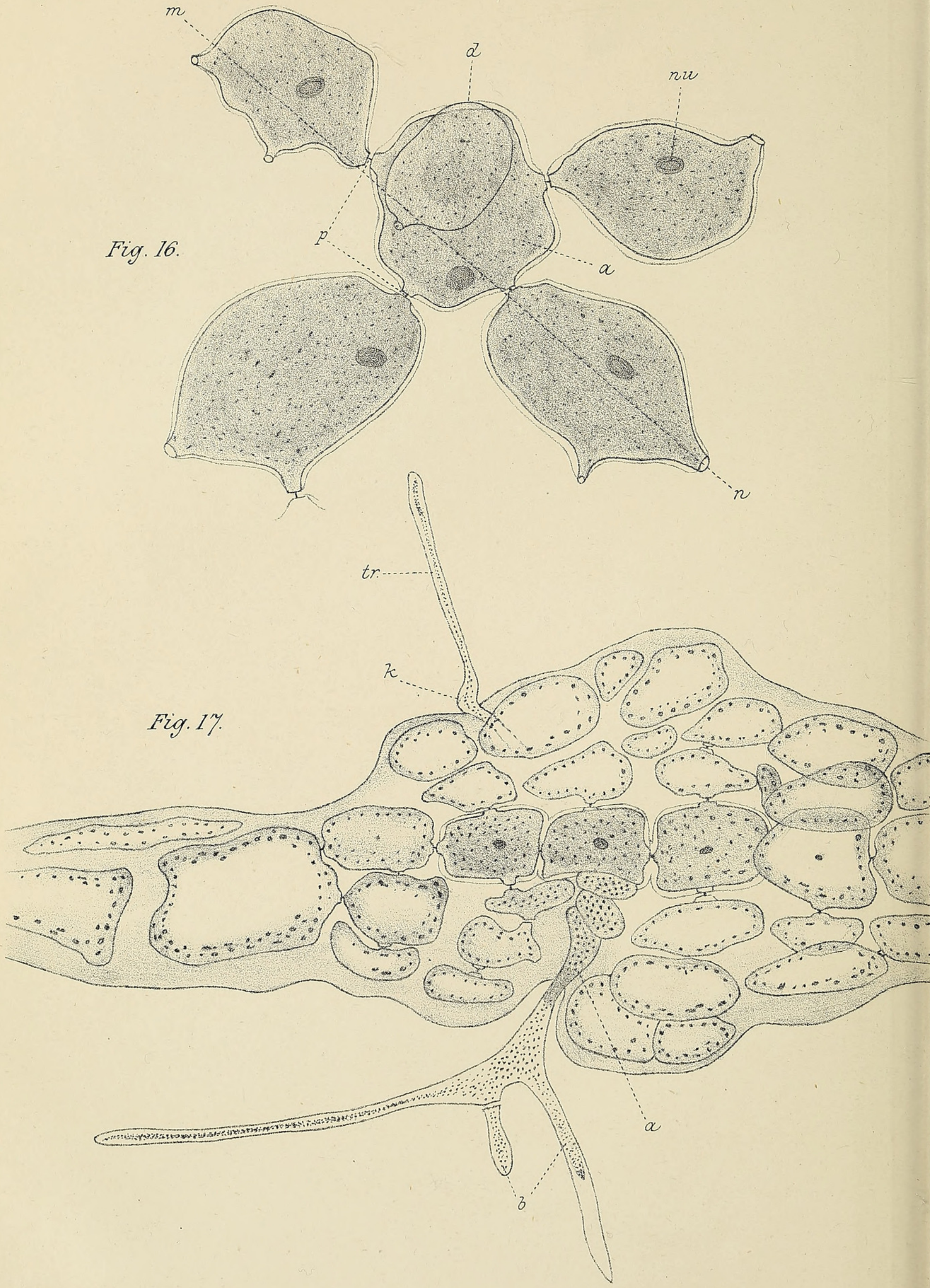

BRANNON.- GRINNELLIA. 
Vol.XI, PL.II.
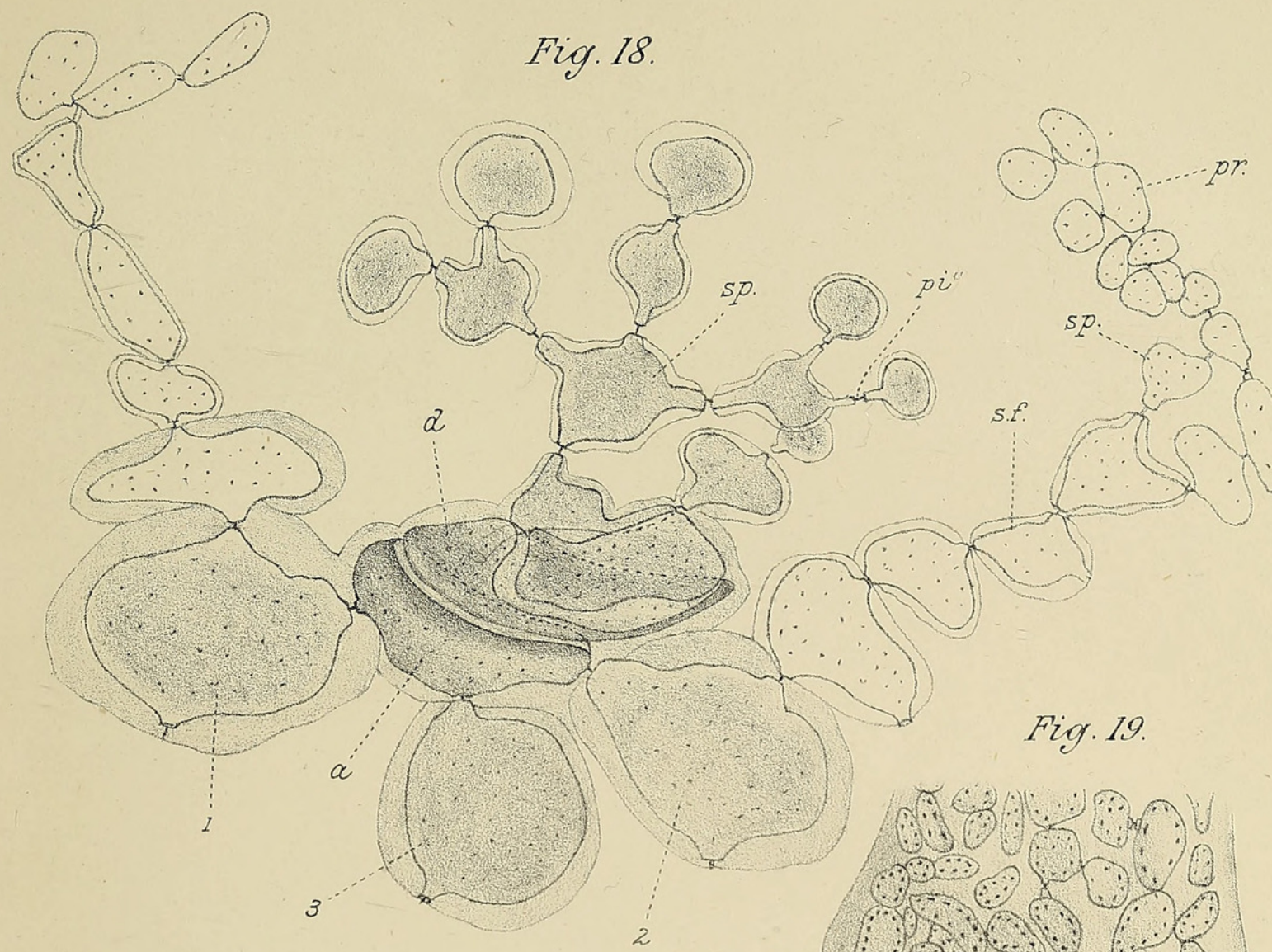

Fig. 19

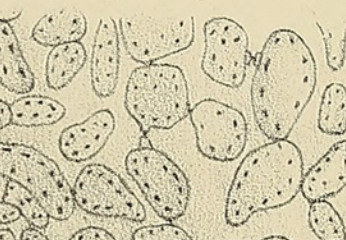

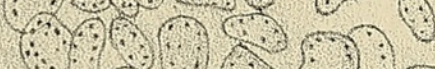

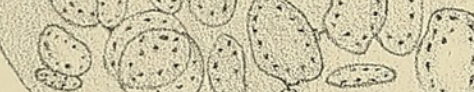

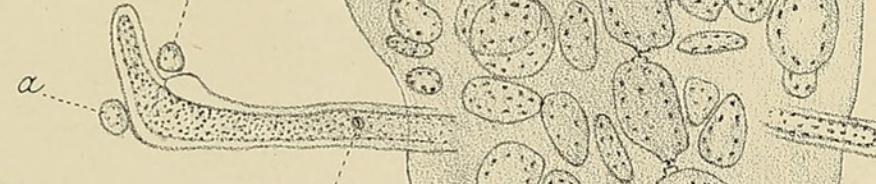

Fig. 20.

$s p$

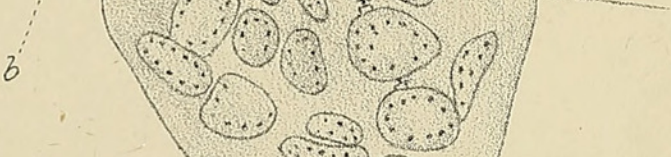

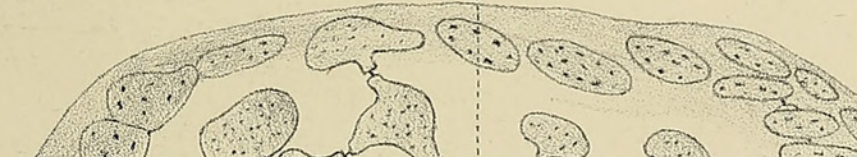

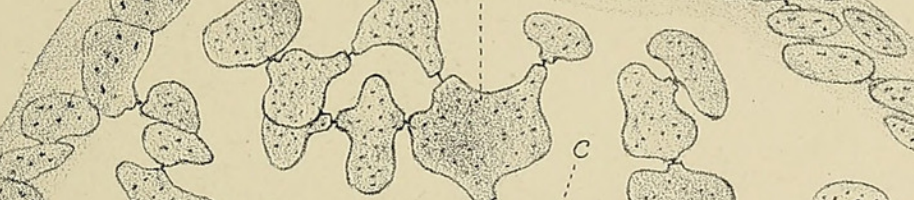

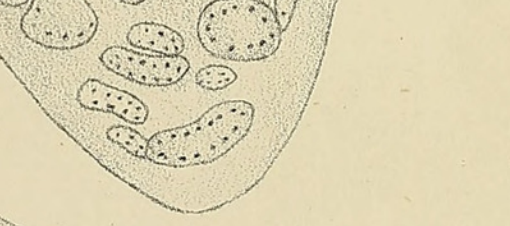

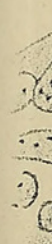

$\rightarrow(4$ (6)

$\therefore \quad \therefore \rightarrow 2$ ?

$\therefore \because$

$\because$

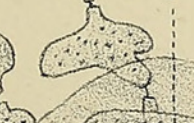

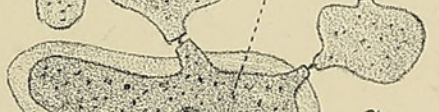

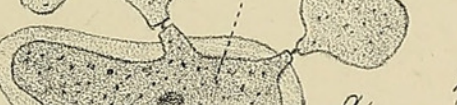

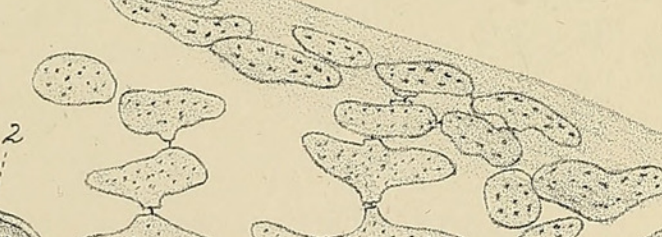

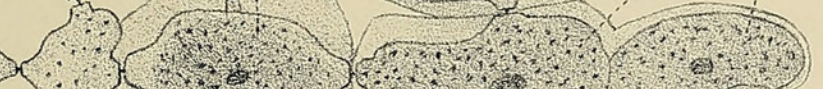

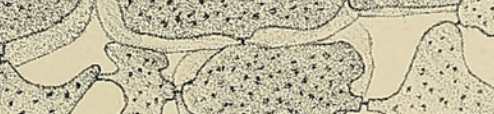

$2=2 \div \because$

2. $\because \because \because 3 \div$

$\because \because 2 \cdots \cdots$

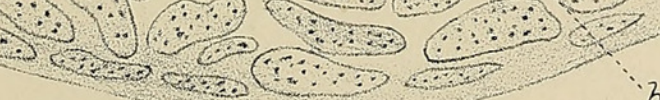

University Press, 0xford. 
Arnats of Botany

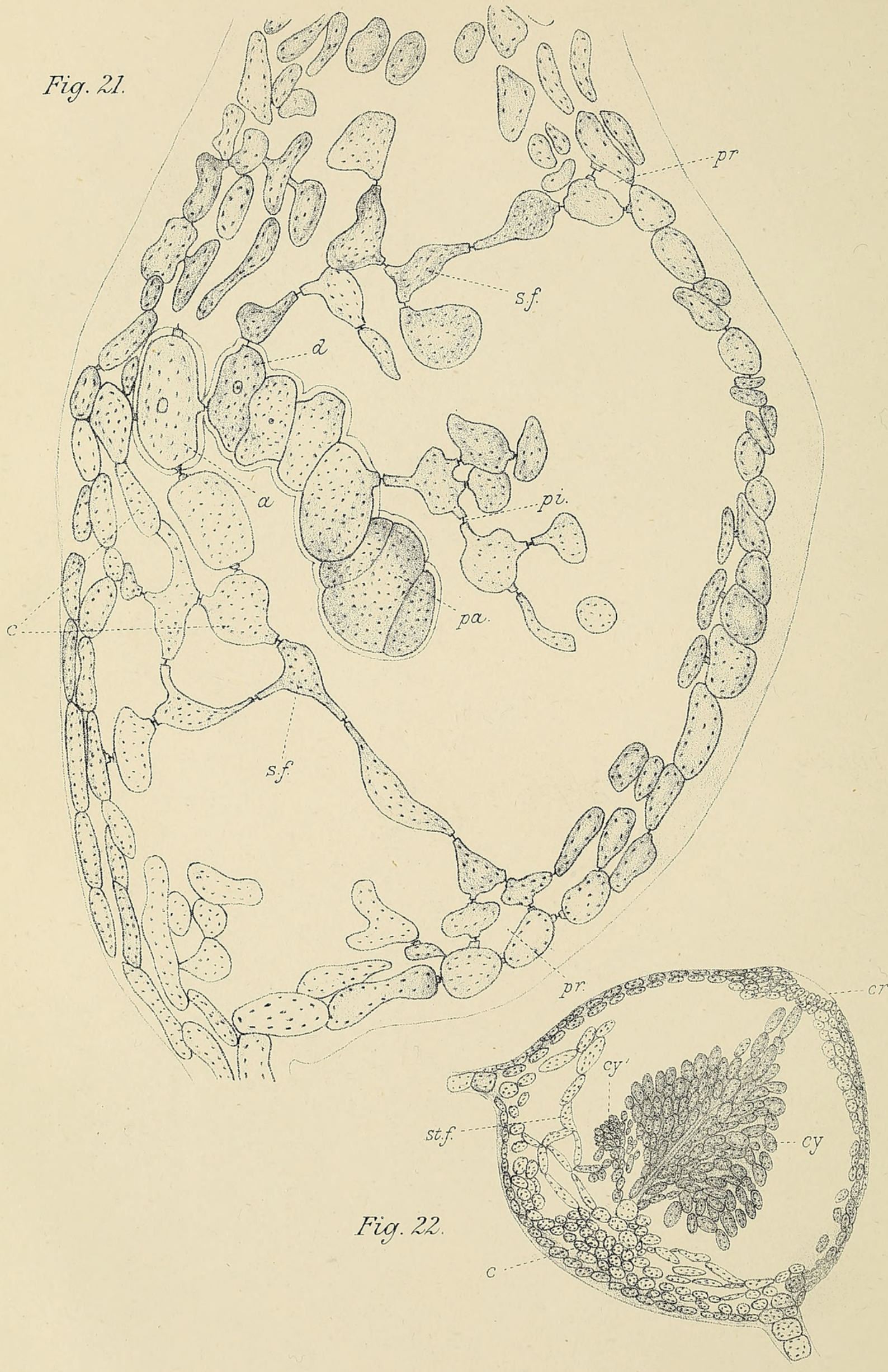

BRANNON.- GRINNELLIA. 
Vol.XI, PU.III.

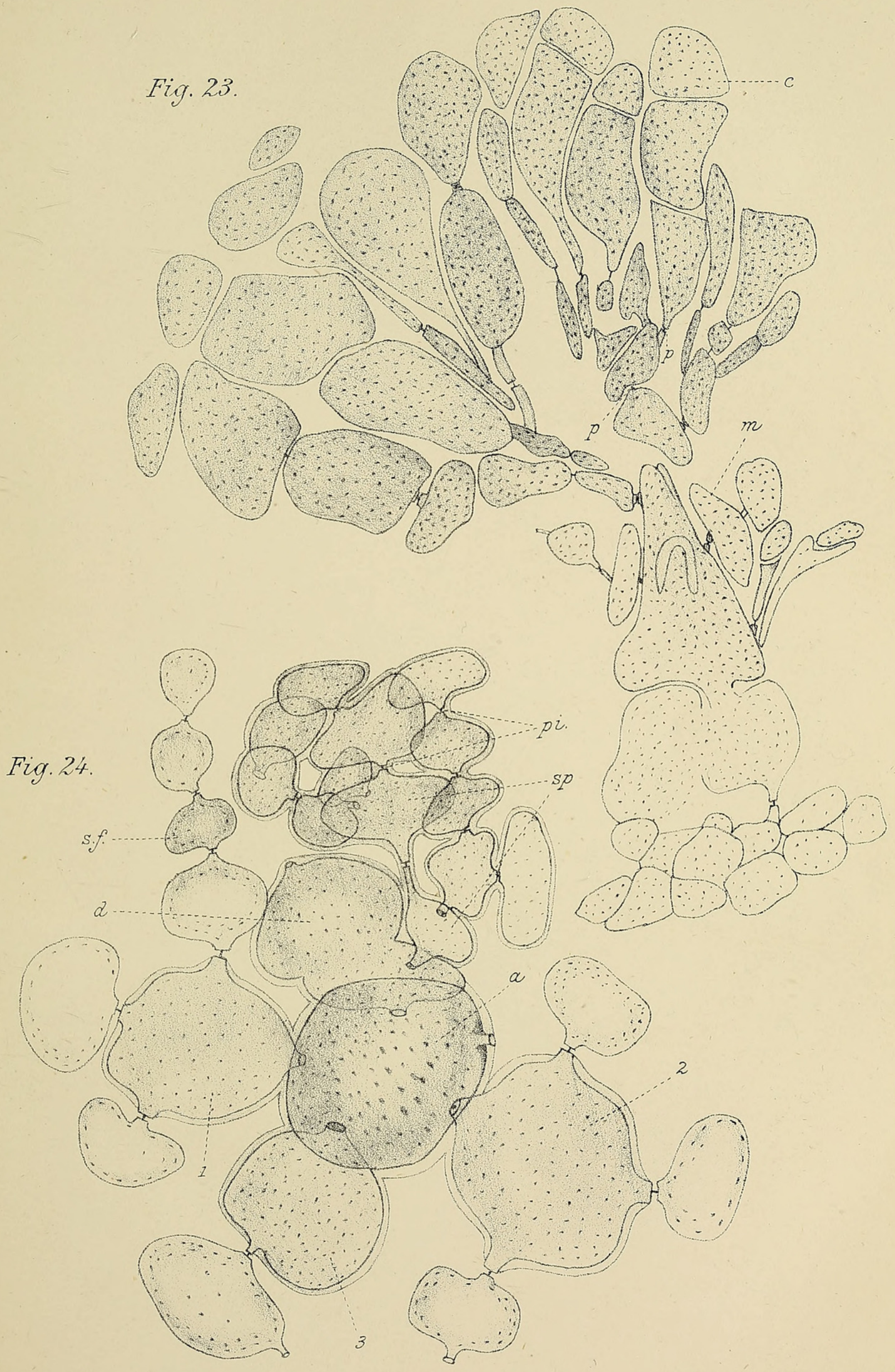




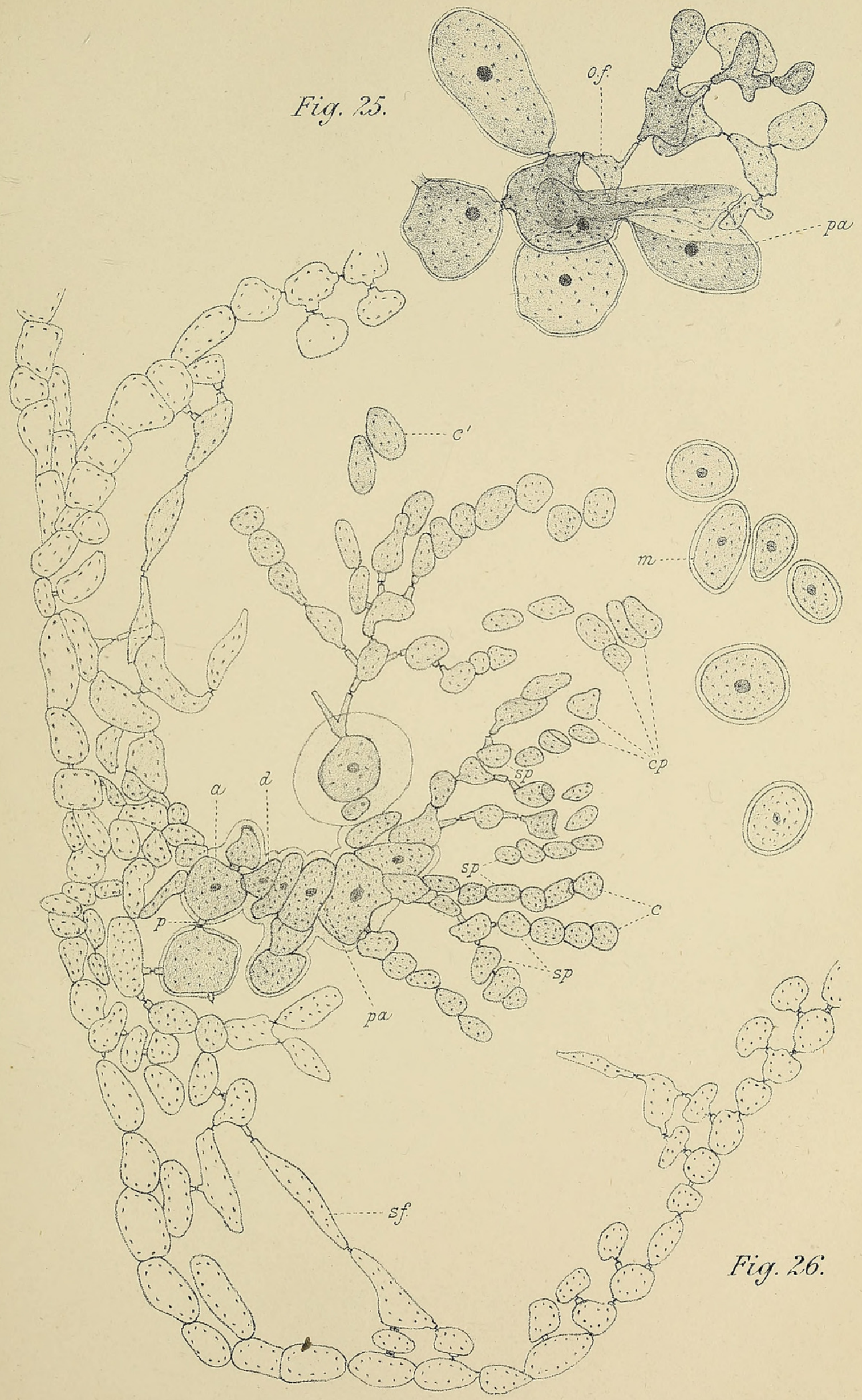

University Press, Oxford. 


\section{$2 \mathrm{BHL}$ Biodiversity Heritage Library}

Brannon, Melvin A. 1897. "The structure and development of Grinnellia americana, Harv." Annals of botany 11, 1-28.

https://doi.org/10.1093/oxfordjournals.aob.a088638.

View This Item Online: https://www.biodiversitylibrary.org/item/233542

DOI: https://doi.org/10.1093/oxfordjournals.aob.a088638

Permalink: https://www.biodiversitylibrary.org/partpdf/318451

\section{Holding Institution}

Smithsonian Libraries

\section{Sponsored by}

Biodiversity Heritage Library

\section{Copyright \& Reuse}

Copyright Status: Not in copyright. The BHL knows of no copyright restrictions on this item.

This document was created from content at the Biodiversity Heritage Library, the world's largest open access digital library for biodiversity literature and archives. Visit BHL at https://www.biodiversitylibrary.org. 